\title{
SIDE EFFECTS OF ADJUVANT RADIOTHERAPY IN MEN WITH TESTICULAR SEMINOMA STAGE I*
}

\author{
Marija GAMULIN, Mislav GRGIĆ, and Vesna BIŠOF \\ Clinical Hospital Centre Zagreb, Department of Oncology, Zagreb, Croatia \\ Received in June 2011 \\ CrossChecked in August 2011 \\ Accepted in August 2011
}

\begin{abstract}
In this study we followed up the side effects of adjuvant radiotherapy in patients with testicular seminoma stage I over a period from 13 to 84 months (median 28 months). The most frequent side effects during radiotherapy were gastrointestinal (nausea/vomiting), psychological, cognitive, and minor sexual problems. The reported side effects were treated by antiemetics and anxiolytics.

After radiotherapy, the side effects persisted in $6 \%$ of patients, but only a few of them required additional treatment. Healthy children were born to $76 \%$ of patients in the 18 to 39 years age group. This study shows that adjuvant radiotherapy of the para-aortic lymph nodes with the total dosage of $24 \mathrm{~Gy}$ in 16 daily fractions administered to testicular seminoma patients causes acceptable side effects, does not adversely affect quality of life and fertility, if the approach to treatment is individual and family consulting is provided. This makes adjuvant radiotherapy of the para-aortic lymph nodes an acceptable treatment for testicular seminoma stage I patients.
\end{abstract}

KEY WORDS: early stage seminoma, follow-up, para-aortic radiotherapy, quality of life, radiation toxicity

Testicular germ cell tumours are relatively rare, appearing in $1 \%$ of all tumours in male patients (1). Most of these tumours originate in germ cells (seminoma and non-seminoma germ cell testicular tumours, sometimes the combination of these two groups), and more than $70 \%$ of patients are diagnosed the disease while it is still in stage I. These malignancies represent the most common solid tumours in young men aged 25 to 35 years and are highly curable.

Pure seminoma is the most common variant of testicular germ cell tumours, accounting for in about $40 \%$ of all cases. Seminoma is highly radiosensitive and chemosensitive (2). Adjuvant radiotherapy of the para-aortic lymph nodes after orchidectomy is one of

* Partly presented at the $8^{\text {th }}$ Symposium of the Croatian Radiation Protection Association with international participation, Krk, Croatia 13-15 April 2011 the three approaches to management, which include surveillance, adjuvant radiotherapy (infradiaphragmatic 20 Gy to 25 Gy to include the para-aortic nodes), and adjuvant chemotherapy with carboplatin with area under the curve $=7,(\mathrm{AUC}=7) \times 1$ cycle or $\mathrm{AUC}=7 \mathrm{x}$ 2 cycles (3-6).

Many surveillance studies suggest that $15 \%$ to $20 \%$ of these patients develop a metastatic disease. The adjuvant therapy is successful in $96 \%$ to $100 \%$ of patients $(4,7,8)$. Many studies suggest that carboplatin is not inferior to adjuvant radiotherapy in preventing metastatic relapse. The estimation of the therapy success, however, should include the quality of life during as well as after therapy. To improve the quality of life, it is therefore advisable to know which side effects to expect and how to prevent them). 
The aim of this study was to establish the side effects during and after radiotherapy in patients with testicular seminoma stage I and how to prevention and/or treat them.

References provide numerous data on toxicity of radiotherapy in the adjuvant treatment of testicular seminoma. Most of the clinical studies of long-term surveillance are based on larger irradiation fields or higher daily doses. There are neither sufficient data on the long-term surveillance of patients treated with irradiation of the para-aortic fields, nor on the adjuvant chemotherapy with carboplatin. The usual toxicity after radiotherapy and chemotherapy is either the acute toxicity during and immediately after therapy, or the late or postponed toxicity monitored years after the therapy.

Acute toxicity usually involves mild gastrointestinal symptoms and the symptoms of myelosuppression, but late effects may include radiation-induced secondary malignancies, increased risk of peptic ulceration, and impaired fertility, and sexual function (9-11).

\section{SUBJECTS AND METHODS}

The study included 115 patients with testicular seminoma stage I, treated with adjuvant radiotherapy at the Clinical Hospital Centre Zagreb, Department of Oncology. The average patient age at diagnosis was
34 (19 to 72 ) years. Their socio-demographic characteristics are summarised in Table 1. All patients were treated with adjuvant radiotherapy of the paraaortic lymph nodes with $15 \mathrm{MV}$ linear accelerator photons from two opposite anteroposterior fields. The tumour dose was 24 Gy divided in 16 daily fractions. Para-aortic field borders included superior T10/T11 intervertebral disk, inferior L5/S1 intervertebral disk, lateral margins to the vertebral bodies including the transverse process bilaterally (Figure 1a,1b,1c), and the left renal hilum for the left testicular seminoma. The patients wore a gonadal shield. All patients were stage IA or IB. Before orchidectomy, all had standard laboratory tests, tests for serum tumour markers alphafetoprotein (AFP), lactate dehydrogenase (LDH), and beta-human chorionic gonadotropin (bHCG), chest $\mathrm{X}$-rays, abdominopelvic CT scans, and the ultrasound of the testes.

Before radiotherapy (post-orchidectomy), all patients had normal serum tumour markers $\mathrm{LDH}$, bHCG, and AFP. Before orchidectomy $18 \%$ had abnormal bHCG and $14 \%$ abnormal LDH. Follow-up after radiotherapy took place every six months in the first five years, then annualy and included standard laboratory tests, AFP, LDH, and bHCG tests; chest X-rays, abdominopelvic CT scans or MRI, and the ultrasound of the testes.

For the follow-up of radiotherapy side effects we used the European Organisation for Research and Treatment of Cancer(EORTC) QLQ-C30 questionnaire

Table 1 Socio-demographic characteristics of patients $(N=115)$

\begin{tabular}{|c|c|c|c|c|c|c|c|c|}
\hline \multirow{2}{*}{$\begin{array}{l}\text { Age at } \\
\text { diagnosis / } \\
\text { years }\end{array}$} & \multicolumn{3}{|c|}{ Education } & \multicolumn{3}{|c|}{ Marital status } & \multicolumn{2}{|c|}{$\begin{array}{c}\text { Tumours } \\
\text { in the family }\end{array}$} \\
\hline & & $\begin{array}{c}\text { low and } \\
\text { middle }\end{array}$ & high & married & single & common-law & no tumours & tumours \\
\hline 34 & $\mathrm{~N}$ & 82 & 33 & 82 & 28 & 5 & 55 & 60 \\
\hline (19 to 72 ) & $\%$ & 71 & 29 & 71 & 25 & 4 & 48 & 52 \\
\hline
\end{tabular}
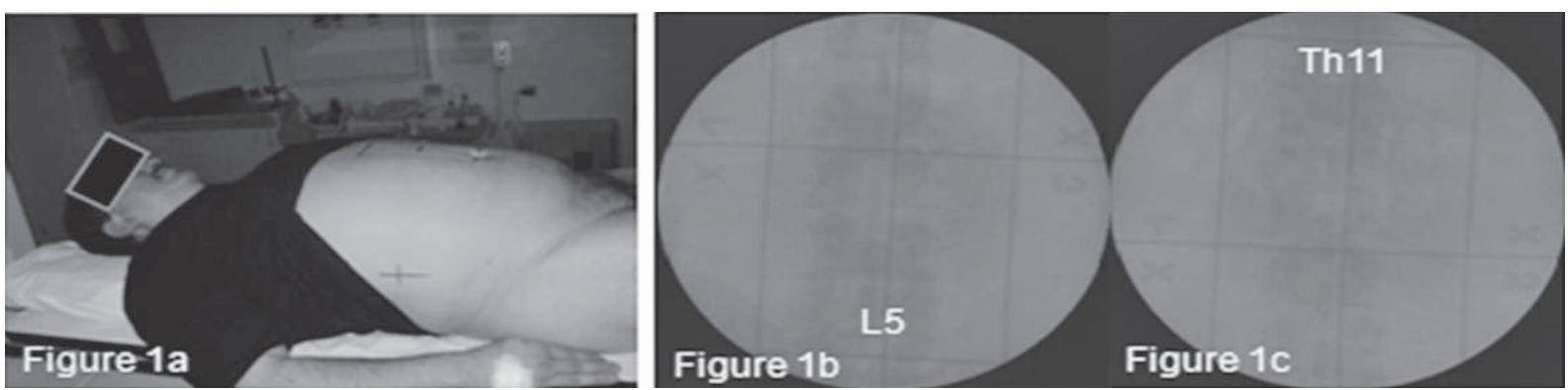

Figure 1a, 1b, 1c Para-aortic fields for early-stage seminoma 


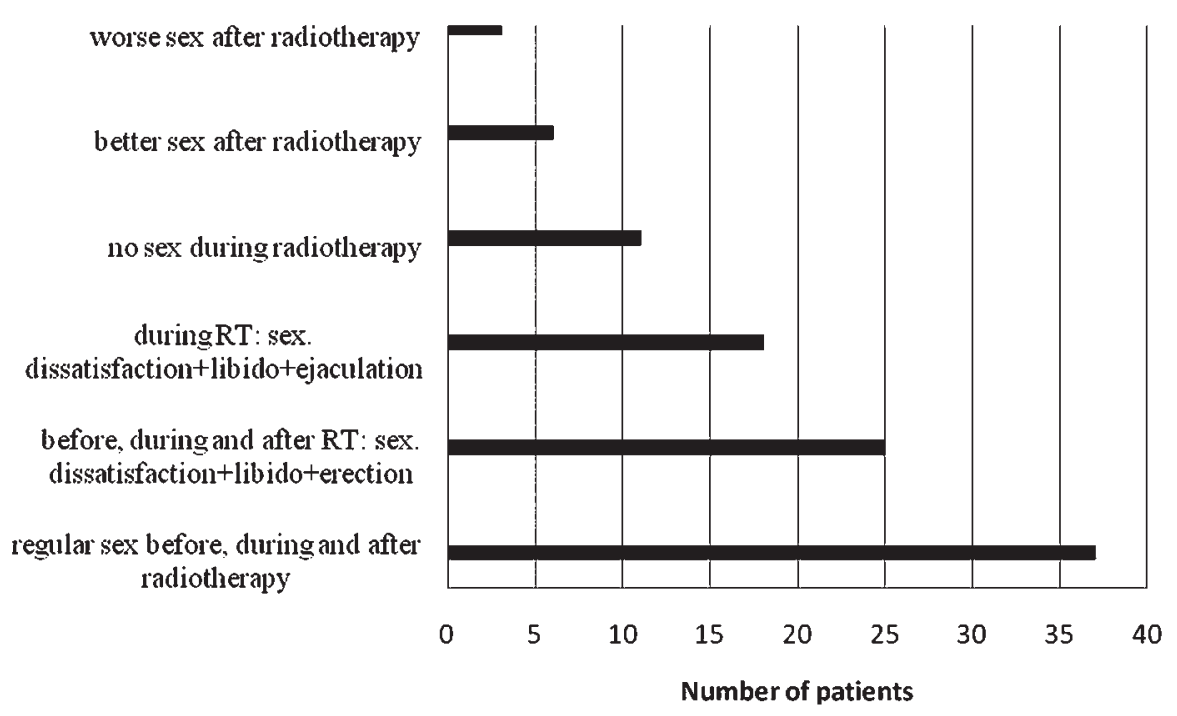

Figure 2 Influence of adjuvant radiotherapy on patients'sexual life

$(12,13)$ and the recommended toxicity criteria of the Radiation Therapy Oncology Group (RTOG) (14). In the questionnaire the patients evaluated the severity of their side effects on a four-point scale: 1) not at all; 2) a little; 3) quite a bit; 4) very much (12). Their physical condition and the quality of life were scored on a seven-point scale from "very poor" to "excellent".

A smaller part of the data was taken from standard routine medical checkup documentation. Patients filled out the questionnaire immediately after radiotherapy and again in December of 2010, which means that the first and the second questionnaire were separated by 13 to 84 months (median 28 months).

\section{RESULTS AND DISCUSSION}

The male population with testicular seminoma is generally of younger age. Due to successful therapy management, long-term survival is excellent. Therefore, seminoma patients are an ideal population to formulate evidence-based guidelines for reducing therapy side effects.

During and after radiotherapy, our patients complained of gastrointestinal side effects, fatigue and diminished fitness, affected psychological and cognitive functions and sexual problems. The sexual side effects are given in Figure 2. Other side effects listed in Table 2 refer to physical well-being, intestinal function, urinary function, pain, psychological well- being, physical autonomy, relational life, body image, job modification, subjective evaluations of global life quality, and the role of treatment in life-style changes. During radiotherapy four patients required treatment of side effects; two with antiemetics (ondansetron hydrochloride, $8 \mathrm{mg} \mathrm{d}^{-1}$ to $16 \mathrm{mg} \mathrm{d}^{-1}$ ) for vomiting which occurred in the first three days of radiotherapy and two with anxiolytics (oral diazepam $2 \mathrm{mg} \mathrm{d}^{-1}$ to 5 $\mathrm{mg} \mathrm{d}^{-1}$ ) in the first week of radiotherapy. One patient had to withdraw from radiotherapy for three days due to thrombocytopenia G1, according to RTOG (14).

After radiotherapy, six patients showed side effects; three required no therapy, while three required therapy occasionally. Occasional side effects were gastritis or stomach pain, which were treated with esomeprazol magnesium $20 \mathrm{mg} \mathrm{d}^{-1}$. One patient had occasional diarrhoea for up to three months after radiotherapy, but required no therapy. A year after radiotherapy, one patient had two episodes of acute pancreatitis, which required hospitalisation. One to six years after radiotherapy, $80 \%$ of the patients aged from 18 to 29 years and $67 \%$ of those aged 30 to 39 years had healthy children.

Two patients had a relapse of seminoma (1.7\%). The first was irradiated in 2008. He had a left testicular seminoma pT2, a lymphatic invasion and extending through the tunica albuginea, pT2N0M0S0, stage IB. The pathohistological tumour size was $4.5 \mathrm{~cm}$. Fourteen months after the para-aortic radiotherapy, CT detected the lymph node size $5.5 \mathrm{~cm} \times 5.6 \mathrm{~cm}$ (outside of the irradiation field) in the left pelvis. He was treated with four cycles of BEP chemotherapy 
and is now healthy. The second patient had a relapse of seminoma in the right inguinal lymphnodes four months after the para-aortic radiotherapy. Initially, he had a right testicular seminoma pT2N0M0S0, stage IB. The pathohistological tumour size was $7.3 \mathrm{~cm}$ with a vascular invasion. He was treated with three cycles of BEP chemotherapy and is now healthy.

Table 2 Side effects during and after radiotherapy

\begin{tabular}{|c|c|}
\hline Side effects & Patient / \% \\
\hline nausea & 25 \\
\hline diarrhoea & 2 \\
\hline vomiting & 1 \\
\hline fatigue & 4 \\
\hline nausea and vomiting & 15 \\
\hline nausea and hard stool & 8 \\
\hline nausea and diarrhoea & 7 \\
\hline nausea, vomiting and diarrhoea & 4 \\
\hline nausea and fatigue & 27 \\
\hline no side effects & 7 \\
\hline $\begin{array}{l}\text { the same weight as before radiotherapy, } \\
\text { no anorexia }\end{array}$ & 46 \\
\hline anorexia with weight loss $\leq 5 \%$ & 28 \\
\hline anorexia with weight loss $\leq 15 \%$ & 23 \\
\hline $\begin{array}{l}\text { body weight increase during } \\
\text { radiotherapy }\end{array}$ & 3 \\
\hline sleep problems & 12 \\
\hline worried and anxious & 35 \\
\hline worried, anxious and depressed & 32 \\
\hline memory and concentration problems & 8 \\
\hline $\begin{array}{l}\text { no sleep problems, anxiety or } \\
\text { depression }\end{array}$ & 13 \\
\hline stomach pains & 16 \\
\hline breathing problems & 4 \\
\hline $\begin{array}{l}\text { financial problems due to absence from } \\
\text { work }\end{array}$ & 21 \\
\hline $\begin{array}{l}\text { social problems (social life and going } \\
\text { out) }\end{array}$ & 23 \\
\hline
\end{tabular}

Physical condition in the last week of radiotherapy

\begin{tabular}{ll}
\hline poor, very poor & 23 \\
\hline medium & 20 \\
\hline good/excellent & 57 \\
\hline
\end{tabular}

Quality of life in the last week of radiotherapy

poor, very poor 14

medium 20

good/excellent
Seminomas are highly sensitive to chemotherapy and radiotherapy. Two management approaches have dominated the clinical practice in the past 20 years: irradiation and survival follow up. Currently, monochemotherapy with carboplatin may be proposed as the third approach. The role of adjuvant monochemotherapy with carboplatin is less established (15-17).

Two Medical Research Council (MRC) studies of 5 years follow-up $(18,19)$ reported significantly lower toxic effects after the radiotherapy of testicular seminoma when the field was reduced from "dogleg" to para-aortic and when the dose was reduced from $30 \mathrm{~Gy}$ to $20 \mathrm{~Gy}$, while the therapy outcome was the same.

A meta-analysis (20) of surveillance studies suggest that risk factors such as the tumour size $>4 \mathrm{~cm}$ and the pathological infiltration of rete testis result in $15 \%$ to $20 \%$ of testicular seminoma in patients with undetectable disease in the para-aortic region. Therefore, follow-up should include patients with no risk factors $(7,21)$. The problem with follow up is the number of patients who come to the control examination irregularly. Beside the side effects, the quality of life is also important parameter included in follow-up.

Opinions are divided on the choice of treatment with carboplatin between one and two cycles and the respective dosage. However, the relapse is less likely with carboplatin in two cycles (AUC 7) (22-25). As for chemotherapy and radiotherapy, present data (4) suggests that the effects of treating testicular seminoma stage I with carboplatin or with irradiation of the paraaortic lymph nodes are identical. This shifts the focus on the side effects as important elements in the correct selection of treatment, in which patient's agreement is part of the decision process (26).

Dose reduction and the limiting of the irradiation field to the para-aortic area seem to reduce the scattered dosage to the remaining testicle, and therefore the risk of impaired fertility and genetic damage. Additionally, the cumulative dose of $2 \mathrm{~Gy}$ in multiple fractions was reported to induce azoospermia, which may be associated with scattered irradiation of the testis from inverted Y field $(27,28)$.

Chemotherapy of Hodgkin's disease alone caused less severe fertility function disturbances than a combination of chemotherapy and pelvic irradiation (48\% vs. $89 \%$ ) (29).

Advances in radiotherapy and chemotherapy with similar results may in near future provide an answer as to which therapy option is less toxic (30). 
Radiotherapy has been the accepted cancer therapy option for at least five decades. Our study describes side effects in patients with testicular seminoma stage I after radiotherapy and is in concordance with similar studies $(11,31)$. According to a large multicentre studies, $4 \%$ to $7 \%$ of patients developed the secondary cancer after radiotherapy of testicular cancer, of which the highest risk was for gastrointestinal cancers $(9$, 32). In the past, however, irradiation fields were larger and so was the total dose of irradiation $(33,34)$. A transparent communication and individual approach to patients will produce the best results and better treatment of radiotherapy side effects. The important problem is the change in sexual activity due to either psychological reasons $(35,36)$ or the awareness of fertility issues $(11,28)$. This study contributes to the current knowledge of patient condition after exposure to ionising radiation, fertility options, side effects in order to identify procedures for resolving patient's problems and improving living conditions as soon after radiotherapy as possible.

\section{REFERENCES}

1. Adami HO, Bergstrom R, Mohner M, Zatooski W, Storm H, Ekbom A, Tretli S, Teppo L, Ziegler H, Rahu M, Gurevicius $\mathrm{R}$, Asengrevics A. Testicular cancer in nine northern European countries. Int J Cancer 1994;59:33-8.

2. Powles TB, Bhardwa J, Shamash J, Mandalia S, Oliver T. The changing presentation of germ cell tumours of the testis between 1983 and 2002. BJU Int 2005;95:1197-2000.

3. Bosl GJ. Patil S. Carboplatin in clinical stage seminoma: Too much and too little at the same time. J Clin Oncol 2011;10:949-52.

4. National Comprehensive Cancer Network v 2.2011. Clinical Practice Guidelines in Oncology. Testicular Cancer [displayed 29/08/2011]. Available at: http://www.nccn.org

5. de Wit R, Fizazi K. Controversis in the management of clinical stage I testis cancer. J Clin Oncol 2006;24:548292.

6. Oliver T. Conservative management of testicular germ-cell tumors. Nat Clin Pract Urol 2007;4:550-60.

7. Warde P, Specht L, Horvich A, Oliver T,Panzarella T, Gospodarowicz M, von der Masse H. Prognostic factors for relapse in stage I seminoma managed by surveillance: A pooled analysis. J Clin Oncol 2002;20:4448-52.

8. Cullen M, James N. Adjuvant therapy for stage I testicular cancer. Cancer Treat Rev 1996;22:253-64.

9. Fossa S.D, Langmark F, Aass N, Andersen A, Lothe R, Borresen AL. Second non-germ cell malignancies after radiotherapy of testicular cancer with or without chemotherapy. Br J Cancer 1990;61:639-43.

10. Hamilton C, Horwich A, Easton D, Peckman MJ. Radiotherapy for stage I seminoma testis: Results of treatment and complications. Radiother Oncol 1986;6:115-20.
11. Aass N, Grünfeld B, Kaalhus O, Fossa D. Pre-and posttreatment sexual life in testicular cancer patients: a descriptive investigation. Br J Cancer 1993;67:1113-7.

12. Aaroson NK, Ahmedzai S, Bergman B, Bullinger M, Cull A, Duez NJ, Flecher H, Fleishman SB, de Haes JCJM, Kaasa S, Klee M, Osoba D, Razavi D, Rofe PB, Schraub S, Sneeuw K, Sullivan M, Takeda F. The European Organization for Research and Treatment of Cancer QLQ-C30: A quality-oflife instrument for use in international clinical trials in oncology. J Nation Cancer Inst 1993;85:365-76.

13. Michelson H, Bolund C, Nilsson B, Brandberg Y. Healthrelated quality of life measured by the EORTC QLQ-C30. Acta Oncol 2000;39:477-84.

14. Cox JD, Joann Stetz BS, Pajak TF. Toxicity criteria of the Radiation Therapy Oncology Group (RTOG) and the European Organization for Research and Treatment of Cancer (EORTC). Int J Rad Oncol Biol Phys 1995;31:1341-6.

15. Oliver RTD, Mason MD, Mead GM,von de Maase H, Rustin GJS, Joffe KJ, de Wit R, Aass N, Graham JD, Coleman R, Kirk SJ, Stenning SP. Radiotherapy versus single-dose carboplatin in adjuvant treatment of stage I seminoma: a randomized trial. Lancet 2005;366:293-300.

16. Oliver RTD, Mead GM, Rustin GJS, Joffe KJ, Aass N, Coleman R, Gabe R, Polloch P, Stenning SP. Randomized trial of carboplatin versus radiotherapy for stage I seminoma: Mature results on relapse and contralateral testis cancer rates in MRC TE19/EORTC30982 Study (ISRCTN27163214). J Clin Oncol 2011;29:957-62.

17. Albers P. Management of stage I testis cancer. Eur Urol 2007;51:34-44

18. Fossa SD, Horwich A, Russel JM, Roberts JT, Cullen MH, Hodson NJ, Yosef H, Duchesne GM, Owen JR, Grosch EJ, Chetiyawardana AD, Reed NS, Widmer B, Stenning SP. Optimal planning target volume for stage I testicular seminoma: A medical research council randomized trial. J Clin Oncol 1999; 17:1146-54.

19. Jones WG, Fossa SD, Mead GM, Roberts JT, Sokal M, Horwich A, Stenning SP. Randomized trial of 30 versus $20 \mathrm{~Gy}$ in the adjuvant treatment of stage I testicular seminoma: A report on medical research council trial TE18. European Organisation for the Research and Treatment Cancer Trial 30942 (ISRCTN18525328). J Clin Oncol 2005;23:1200-8.

20. Hahn NM, Sweeney CJ. Germ cell tumors: An update of recent data and review of active protocols in stage I and metastatic disease. Urol Oncol 2005;23:293-302.

21. Alomary I, Samant R, Genest P, Eapen L, Gallant V. The prefered treatment for stage I seminoma: A survey of Canadian radiation oncologists. Clin Oncol 2006;18:696-9.

22. Dieckman KP, Beuggeboes B, Pichlmeier U, Kuster J, Mullerleile U, Bartels H. Adjuvant treatment of clinical stage I seminoma: Is a single course of carboplatin sufficient? Urology 2000;55:102-6.

23. Aparico J, Germa JR, del Muro XG, Maroto P, Arranz JA, Saens A,Barnadas A, Dorca J, Guma J, Olmos D, Bastus R, Carles J. Almenar D, Sanchez M, Paz-Arez L, Satrustegui JJ, Mellado B, Balil A, Lopez-Brea M,Sanchez A. Riskadapted management for patients with clinical stage I seminoma: The second Spanish Germ Cell Cancer Cooperative Group study. J Clin Oncol 2005;23;8717-23.

24. Powles T, Robinson D, Shamash J, Moller H, Tranter N. Oliver T. The long-term risks of adjuvant carboplatin 
treatment for stage I seminoma of the testis. Ann Oncol 2008;19:443-7.

25. Aparico J, del Muro XG, Maroto P, Paz-Arez L, Alba E, Sanchez A, Terrasa J, Barnadas A, Almenar D, Arranz JA, Sanchez M, Fernandez A, Sastre J, Carles J, Dorca J, Guma J, Yuste AL, Germa JR. Multicenter study evaluating a dual policy of postorchiectomy surveillance and selective adjuvant single-agent carboplatin for patients with clinical stage I seminoma. Ann Oncol 2003;14:867-72.

26. Hoffman EK, Chen MH, Punglia RS, Beard CJ, D'Amico $\mathrm{AV}$. Influence of year of diagnosis, patient age, and sociodemographic status on recommending adjuvant radiation treatment for stage I testicular seminoma. J Clin Oncol 2008;26;3937-42.

27. Bieri S, Rouzaud M, Miralbell R. Seminoma of the testis: Is scrotal shielding necessary when radiotherapy is limited to para-aortic nodes? Radiother Oncol 1999;50:349-53.

28. Majewski W, Majewski S, Maciejewski A, Kolosza Z, Tarnawski R. Adverse effects after radiotherapy for early stage (I, IIa, IIb) seminoma. Radiother Oncol 2005;76:25763.

29. Zadravec Zaletel L, Bratanic N, Jereb B. Gonadal function in patients treated for Hodgkin ' disease in childhood. Radiol Oncol 2010;44:187-93.

30. Martin JM, Panzarella T, Zwahlen DR, Chung P, Werde P. Evidence-based guidelinies for following stage 1 seminoma. Cancer 2007;109:2248-56.
31. Arai Y, Kawakita M, Okada Y, Yoshida O. Sexuality and fertility in long-term survivors of testicular cancer. J Clin Oncol 2007;15;1444-8.

32. van Leeuwen FE, Stiggelbout AM, van den Belt-Dusebout AW, Noyan R, Eliel MR, van Kerkhoff EHM, Delemarre JFM, Somers R. Second cancer risk following testicular cancer: A follow-up study of 1,909 patients. J Clin Oncol 1993;11:415-24.

33. van den Belt-Dusebout AW, de Wit R, Gietema JA, Horenblas S, Louwman MWJ, Ribot JG, Hoestra HJ, Ouwens GM, Aleman BMP, van Leeuwen FE. Treatment-specific risks of second malignancies and cardiovascular disease in 5-year survivors of testicular cancer. J Clin Oncol 2007;25:43708 .

34. Gamulin M, Kopjar N, Grgić M, Ramić S, Viculin T, Petković M, Garaj-Vrhovac V. Cytogenetic follow-up in testicular seminoma patients exposed to adjuvant radiotherapy. Coll Antropol 2010;34:455-65.

35. Reiker PP, Edbril AD, Garnic MB. Curative testis cancer therapy: Psychosocial sequelae. J Clin Oncol 1985;3:111726.

36. Dahl AA, Haaland CF, Mykletun A, Bremnes R, Dahl O, Klepp O, Wist E, Fossa SD. Study of anxiety disorder and depression in long-term survivors of testicular cancer. J Clin Oncol 2005; 23;2389-95. 


\section{Sažetak}

\section{NUSPOJAVE ADJUVANTNOG ZRAČENJA BOLESNIKA SA SEMINOMOM TESTISA STADIJA I}

U ovoj studiji nuspojave adjuvantne radioterapije kod bolesnika sa seminomom testisa stadija I praćene su u periodu od 13 do 84 mjeseca (medijan 28 mjeseci). Tijekom radioterapije bolesnici su imali najčešće nuspojave od strane probavnog sustava (mučnina/povraćanje), psihološke i kognitivne probleme i blaže seksualne smetnje. Navedene nuspojave uspješno su tretirane antiemeticima i anksioliticima. Nakon radioterapije $76 \%$ bolesnika dobne skupine od 18 do 39 godina ima zdravu djecu. Zaključno, ovo istraživanje pokazuje da adjuvantno zračenje paraaortalnih limfnih čvorova s ukupnom dozom od 24 Gy u 16 frakcija kod bolesnika sa seminomom testisa stadija I uzrokuje prihvatljive nuspojave uz prihvatljivu kvalitetu života, fertilitet, koristeći individualni pristup liječenju te obiteljsko savjetovalište. Adjuvantna radioterapija seminoma testisa stadija I je prihvatljiv oblik liječenja.

KLJUČNE RIJEČI: kvaliteta života, paraaortalno polje zračenja, praćenje, radioterapijska toksičnost, rani stadij seminoma

\section{CORRESPONDING AUTHOR:}

Marija Gamulin, MD, Phd

Clinical Hospital Centre Zagreb

Kišpatićeva 12, 10000 Zagreb, Croatia

E-mail:marija.gamulin@zg.t-com.hr 